\title{
Competition Between Pyrimorph-Sensitive and Pyrimorph-Resistant Isolates of Phytophthora capsici
}

\author{
Zhili Pang, JingPeng Shao, Jian Hu, Lei Chen, Zhiwen Wang, Zhaohai Qin, and Xili Liu
}

First, second, third, fourth, fifth, and seventh authors: Department of Plant Pathology, College of Agriculture and Biotechnology, China Agricultural University, Beijing, 100193, P.R. China; and sixth author: Department of Applied Chemistry, College of Science, China Agricultural University, Beijing, 100193, P.R. China.

Accepted for publication 26 September 2013.

\begin{abstract}
Pang, Z., Shao, J., Hu, J., Chen, L., Wang, Z., Qin, Z., and Liu, X. 2014. Competition between pyrimorph-sensitive and pyrimorph-resistant isolates of Phytophthora capsici. Phytopathology 104:269-274.

Phytophthora capsici causes significant losses to vegetable production worldwide. Pyrimorph, a new carboxylic acid amide fungicide, has been registered to control P. capsici in China. A mutation (Q1077K) in cellulose synthase 3 has been reported to confer resistance to pyrimorph. In this study, we measured the competition between pyrimorph-resistant and pyrimorph-sensitive isolates of $P$. capsici. Mixed zoospore suspensions of resistant $(\mathrm{R})$ and sensitive $(\mathrm{S})$ isolates at five ratios (1R:9S, 3R:7S, 5R:5S, 7R:3S, and 9R:1S) were applied to carrot agar in vitro test

(with five successive transfers) and to the soil surface around pepper plants in planta test (with 10 successive disease cycles). The proportion of resistant isolates was measured by a conventional assay in which single zoospore isolates recovered after transfers or disease cycles were grown on agar medium with a discriminatory concentration of pyrimorph. The results were then compared with those of a real-time polymerase chain reaction (PCR)-based method developed here, the results were similar. Both assays showed that the competitive ability of the resistant isolates was similar to or less than that of the sensitive isolates. The real-time PCR assay developed will be useful for high-throughput analysis and monitoring the development of pyrimorph resistance in field populations of $P$. capsici.
\end{abstract}

The filamentanous oomycete pathogen Phytophthora capsici Leonion, which was first recovered from chili pepper (24), has a wide host range that includes solanaceous plants, snap and lima beans, and cucurbits $(10,11,16,17,23)$. $P$. capsici causes devastating crop losses worldwide $(11,15-17,23)$. Because the resistance of cultivars has not been durable, management of diseases caused by $P$. capsici is mainly based on the integration of several cultural methods and the application of fungicides including carboxylic acid amide (CAA) fungicides $(20,32,35,40)$.

Pyrimorph, (E)-3-[(2-chloropyridine-4-yl)-3-(4-tert-butylphenyl)-acryloyl] morpholine, a novel CAA fungicide, exhibits high activity against some oomycete plant pathogens including $P$. capsici (42). Currently, pyrimorph has been patented for the control of diseases caused by Phytophthora in China and the United States $(5,6,14,36)$ and has been registered for the management of $P$. capsici in China since 2010 (http://www.chinapesticide. gov.cn). The mechanism of action of pyrimorph against $P$. capsici evidently involves the inhibition of energy production and the disturbance of cell wall biosynthesis (42). Laboratory studies showed that the resistance of $P$. capsici to pyrimorph resulted from a point mutation causing the change from glutamine to lysine at position 1077 in the gene encoding cellulose synthase 3 (CesA3) (30).

Mutations associated with fungicide resistance may reduce the fitness of the resistant isolates in the absence of selection pressure from the fungicide $(18,25)$. Fitness, which can be defined as the survival and reproductive success of an allele, individual, or group (34), has an important role in the development and evolution of

Corresponding author: X. Liu, E-mail address: seedling@cau.edu.cn

* The $\boldsymbol{e}$-Xtra logo stands for "electronic extra" and indicates that the online version contains one supplemental figure.

http://dx.doi.org/10.1094/PHYTO-07-13-0185-R

(c) 2014 The American Phytopathological Society fungal populations with fungicide resistance $(31,33)$. Our previous study showed that the predicted fitness (i.e., fitness indicated by sporulation, cystospore germination, and pathogenicity) of mutants of $P$. capsici with resistance to pyrimorph was similar to or less than that of the wild type (30). However, realized fitness termed competition between resistant and sensitive isolates (3) (i.e., fitness determined by competitive experiments) may depend not only on the characteristics measured by predicted fitness but also on the host-pathosystem under investigation; realized fitness may differ from predicted fitness (8). Optimizing the management of diseases caused by $P$. capsici requires detailed knowledge of the realized fitness of the pyrimorph-resistant strains.

The conventional method used to evaluate the proportion of fungicide-resistant isolates in a population involves the culturing of isolates on fungicide-amended media which is time consuming and labor intensive (26). Therefore, an efficient and rapid method is needed for evaluation of fungicide resistance in $P$. capsici. Quantitative real-time polymerase chain reaction (PCR) and other molecular techniques have been used to detect and quantify fungicide-resistant genes in field populations of several other pathogens $(19,26)$.

The objectives of our study were to determine the in vitro and in planta competitive ability of pyrimorph-sensitive and pyrimorph-resistant isolates of $P$. capsici, and to develop a real-time PCR-based assay in order to quantify the frequency of the pyrimorph-resistant allele Q1077K in $P$. capsici populations and in order to evaluate the competitive fitness of pyrimorph-resistant isolates.

\section{MATERIALS AND METHODS}

Isolates of $\boldsymbol{P}$. capsici. Two wild-type isolates ( $\mathrm{Hd} 3$ and $\mathrm{Hd} 11)$ and two pyrimorph-resistant mutants (R3-2 and R11-1) of $P$. capsici were used. The resistant mutants were obtained by repeated exposure of the parents (Hd3 for R3-2 and Hd11 for R11-1) to 
pyrimorph (30). Single-zoospore progeny of each isolate were obtained as described previously (22) with some modifications. Isolates of $P$. capsici were cultured on carrot agar (CA) in Petri dishes (juice of $200 \mathrm{~g}$ of ground carrots filtered with a cheese cloth, $14 \mathrm{~g}$ of agar, and distilled water up to 1 liter) for 4 days in the dark at $25^{\circ} \mathrm{C}$. Then the plates were placed under florescent light with 12 -h light $/ 12$-h dark at $25^{\circ} \mathrm{C}$. After 5 to 7 days, when sufficient numbers of sporangia had been produced, plates were flooded with $10 \mathrm{ml}$ of sterile-distilled water. Following a chilling treatment at $4^{\circ} \mathrm{C}$ for $30 \mathrm{~min}$, cultures were moved to room temperature $\left(25^{\circ} \mathrm{C}\right)$ for 30 to $60 \mathrm{~min}$ to encourage zoospore release. Zoospore suspensions of each isolate were spread onto $1.5 \%$ (wt/vol) water agar. After 8 to $12 \mathrm{~h}$ at $25^{\circ} \mathrm{C}$ in the dark, single germinated zoospores were inspected with a light microscope and transferred to potato dextrose agar (PDA) plates. For preparation of PDA, $200 \mathrm{~g}$ of potato tubers was boiled for $0.5 \mathrm{~h}$, and the material was filtered through four layers of cheesecloth before $18 \mathrm{~g}$ of glucose and $15 \mathrm{~g}$ of agar were added; sufficient distilled water was then added to increase the volume to 1 liter. Before addition to plates, both CA and PDA were autoclaved at $121^{\circ} \mathrm{C}$ for $20 \mathrm{~min}$. For storage, plugs taken from the expanding edge of a culture were transferred to sterile-distilled water and maintained in the dark at $18^{\circ} \mathrm{C}(39)$.

Determination of the concentration of pyrimorph that can be used to discriminate between resistant and sensitive isolates of $\boldsymbol{P}$. capsici isolates. The four isolates of $P$. capsici were used to determine the pyrimorph concentration that could discriminate between pyrimorph-resistant and pyrimorph-sensitive isolates in a mycelial growth assay according to a previously described procedure (28). Each isolate was cultured on PDA plates for 4 days at $25^{\circ} \mathrm{C}$ in the dark. Mycelial plugs were taken from the colony margin with a cork borer $(5 \mathrm{~mm})$ and placed mycelia-side down in the center of PDA plates (one plug per plate) amended with serial concentrations of pyrimorph $(95 \%$ active ingredient [a.i.], provided by Professor Zhaohai Qin, Department of Applied Chemistry, College of Science, China Agricultural University). To discriminate between resistant and sensitive isolates of $P$. capsici, the PDA plates containing 0 , $0.1875,0.375,0.75,1.5,3,4,6,8$, or $10 \mu \mathrm{g}$ of pyrimorph/ml were used for testing the sensitive isolates ( $\mathrm{Hd} 3$ and $\mathrm{Hd} 11$ ) and 0,5 , $10,15,20,25$, or $30 \mu \mathrm{g}$ of pyrimorph $/ \mathrm{ml}$ for testing the resistant mutants (R3-2 and R11-1). Each combination of isolate and concentration was represented by three plates, and the experiment was performed three times. After incubation at $25^{\circ} \mathrm{C}$ for 5 days in darkness, colony diameters were measured, and the average percentage of growth (relative to the growth on plates without pyrimorph) was calculated. The discriminatory concentration, i.e., the pyrimorph concentration that permitted growth of resistant isolates but prevented growth of the sensitive isolates, was determined to be $15 \mu \mathrm{g} / \mathrm{ml}$ (see Results).

Competitive ability in vitro. The in vitro competitive ability was determined for two combinations of the sensitive (S) isolates and their resistant (R) mutants: Hd3 versus R3-2 and Hd11 versus R11-1. Each combination consisted of five ratios of the $S$ and $R$ isolates (9R:1S, 7R:3S, 5R:5S, 3R:7S, and 1R:9S), which were prepared by mixing the zoospore suspensions of the pyrimorphsensitive isolates and the corresponding resistant mutants. Zoospore suspensions were prepared as described earlier, and the final concentration for each was adjusted to $1 \times 10^{5} / \mathrm{ml}$ with the aid of a hemacytometer and microscope. A 100- $\mu$ l volume of each of the resulting zoospore suspensions was spread on a CA plate, and the cultures were grown and zoospores were harvested as described earlier. This procedure was repeated five times (five subcultures). After the first and fifth subculture, 80 single zoospore isolates were obtained and transferred to PDA plates, which were incubated in the dark at $25^{\circ} \mathrm{C}$. After 3 days, plugs of the single-zoospore isolates were transferred to PDA plates amended with the discriminatory concentration of pyrimorph $(15 \mu \mathrm{g} / \mathrm{ml})$, and plates were incubated for another 5 days. Isolates that were able to grow on the plates amended with the discriminatory concentration of pyrimorph were considered resistant, and those that could not were considered sensitive. The ratios of the resistant and sensitive isolates obtained after subculture on CA were calculated and compared with the original ratios. This experiment was performed twice.

Competitive ability in planta. Pepper seedlings (cultivar Tedaqiemen) were grown in planting trays composed of 50 cells (each cell was $5 \mathrm{~cm} \times 5 \mathrm{~cm})$ in a greenhouse $\left(27 \pm 2{ }^{\circ} \mathrm{C}, 80 \%\right.$ relative humidity, and 12-h light/12-h dark). When the plants had four to six leaves (29), they were inoculated with each combination and each ratio of $P$. capsici zoospores, which were prepared as described in the previous section. Each plant was inoculated by soil drench with $3 \mathrm{ml}$ of the mixed zoospore suspension at $1 \times 10^{4}$ zoospores per $\mathrm{ml}$ (30). To prevent movement of inoculum between plants, the trays were kept on metal screens, which allowed any excess water and/or zoospores to drain. Ten seedlings were inoculated for each mixture. The diseased pepper stems were collected 7 days after inoculation, and isolates of $P$. capsici were recovered using the method described previously (37). Zoospore suspensions of each ratio were produced from the isolates recovered and used for subsequent inoculation of plants. Ten successive disease cycles of inoculation-isolation were conducted, and zoospores obtained from the first, fifth, and tenth cycle were evaluated for the ratio of pyrimorph-resistant and pyrimorphsensitive isolates with the same method that was used for in vitro determination of competitive ability. Competitive ability was determined by comparing the ratios of pyrimorph-resistant and pyrimorph-sensitive isolates obtained after inoculation and isolation from pepper plants with the original ratios. The experiment was repeated twice.

Detection and quantification of the Q1077K mutation by a real-time PCR-based method. A single-point mutation at codon position 1077 in the PcCesA3 gene has been reported to be responsible for the resistance of $P$. capsici to pyrimorph (30). A primer pair specific to the pyrimorph-resistant allele was designed to amplify a 124-bp PCR product only in resistant isolates: RF (5'-TCTTCGGGTTATTCGTGATGAGTA-3') + RR (5'-ACCAC CAGAAGCGAACCGAAC-3'). Another primer pair specific to the sensitive allele was designed to amplify a 167-bp band only from sensitive isolates: SF (5'-CTTCGGGTTCTTCGTAATG AGTC-3') + SR (5'-CTTCGTAGTAGACCTGCCACA-3'). DNA of the resistant (R3-2 and R11-1) and sensitive isolates (Hd3 and Hd11) was extracted by a CTAB (hexadecyltrimethylammonium bromide) procedure (38).

Real-time PCR amplification was performed in the ABI PRISM 7500 Real-Time PCR System using the SYBR Green II fluorescent dye detection. The reaction was conducted in a $25-\mu \mathrm{l}$ volume containing $10 \mu \mathrm{l}$ of SYBR Premix DimerEraser $(2 \times)$, $0.4 \mu \mathrm{l}$ of ROX Reference Dye Dye II (50x), $2 \mu \mathrm{l}$ of template DNA, $0.6 \mu \mathrm{l}$ of each of the forward and reverse primers $(10 \mu \mathrm{M})$, and $6.4 \mu \mathrm{l}$ of $\mathrm{dd}_{2} \mathrm{O}$. The following program was used for real-time PCR: an initial preheat for $30 \mathrm{~s}$ at $95^{\circ} \mathrm{C}$; followed by 40 cycles at $95^{\circ} \mathrm{C}$ for $5 \mathrm{~s}, 58^{\circ} \mathrm{C}$ for $30 \mathrm{~s}$, and $72^{\circ} \mathrm{C}$ for $34 \mathrm{~s}$; and a final extension at $95^{\circ} \mathrm{C}$ for $30 \mathrm{~s}$. After the amplifications were completed, melting curves were obtained based on a standard protocol and used to confirm that the target products did not contain primerdimers. To create a standard curve for the quantitative detection of pyrimorph-resistant isolates, 10-fold serial dilutions of the DNA (ranging from 0.001 to $100 \mathrm{ng}$ ) from resistant isolate R3-2 were subjected to real-time PCR assay with the primer pair RF + RR. Also included were one positive control (template DNA from resistant isolate R11-1) and two negative controls (template DNA from the sensitive isolates $\mathrm{Hd} 3$ and $\mathrm{Hd} 11$, and no template DNA). The same procedure was used to create a standard curve for quantifying the pyrimorph-sensitive isolates, except that the resistant isolate R3-2 and the primer pair RF + RR were replaced by the 
sensitive isolate $\mathrm{Hd} 3$ and the primer pair $\mathrm{SF}+\mathrm{SR}$; template DNA of the sensitive isolate Hd11 was used as a positive control, and template DNA of the resistant mutants R3-2 and R11-1 and no template DNA were used as negative controls. Each sample was represented by three replicate templates, and the experiment was conducted three times.

For each sample, the quantity of DNA was determined using the corresponding standard curve. Two real-time PCR amplifications were conducted in the same run: one amplification used the primer pair RF + RR and targeted the resistant Q1077K allele, and the other used the primer pair SF + SR and targeted the sensitive Q1077 allele. The frequency of the Q1077K allele in each sample (FK) was calculated by the following formula: $\mathrm{FK}=$ $\mathrm{Q}_{\mathrm{K}} /\left(\mathrm{Q}_{\mathrm{Q}}+\mathrm{Q}_{\mathrm{K}}\right)$, where $\mathrm{Q}_{\mathrm{K}}$ is the quantity (ng) of template DNA with the resistant allele as determined with the primer pair RF + $\mathrm{RR}$, and $\mathrm{Q}_{\mathrm{Q}}$ is the quantity of template DNA with the sensitive allele as determined with the primer pair $\mathrm{SF}+\mathrm{SR}$.

The real-time PCR assay for determining the frequency of mutant Q1077K allele was evaluated with samples containing mixtures of zoospore suspensions of pyrimorph-resistant mutant R3-2 and pyrimorph-sensitive isolate $\mathrm{Hd} 3$. As described earlier, seven mixtures of these two isolates were made: $100 \% \mathrm{R}, 90 \%$ $\mathrm{R}+10 \% \mathrm{~S}, 70 \% \mathrm{R}+30 \% \mathrm{~S}, 50 \% \mathrm{R}+50 \% \mathrm{~S}, 30 \% \mathrm{R}+70 \% \mathrm{~S}$, $10 \% \mathrm{R}+90 \% \mathrm{~S}$, and $100 \% \mathrm{~S}$. Three replicates of each mixture were used for DNA extraction following the procedure described earlier. The final DNA of each sample was dissolved in $50 \mu \mathrm{l}$ of $\mathrm{ddH}_{2} \mathrm{O}$. A 2- $\mu$ l aliquot of this dilution was used as template DNA for the real-time PCR amplification. The experiment was conducted three times. Linear regression was used to determine the relationship between the mean FK values detected with the real-

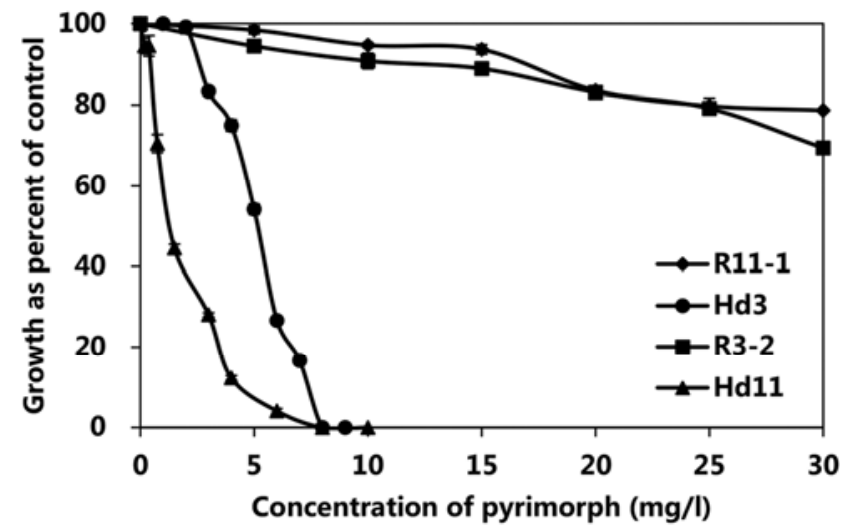

Fig. 1. Sensitivity of hyphal growth of wild-type isolates (Hd3, Hd11) and pyrimorph-resistant isolates (R3-2, R11-1) of Phytophthora capsici to pyrimorph. Values are means ( \pm standard error) of three replications. time PCR assay for replicate mixtures and the percentages of the pyrimorph-resistant mutant in the mixtures.

Comparison of the real-time PCR-based assay with the conventional method. After the end of the fifth cycle of the in vitro competition assay and the tenth cycle of the in planta competition assay (the assays described earlier), DNA was extracted from the final mixtures used for single zoospore isolation by the conventional method following the procedure described above. For each sample, the final DNA was dissolved in $50 \mu \mathrm{l}$ of $\mathrm{ddH}_{2} \mathrm{O}$, and a 2- $\mu$ l aliquot of the template DNA was used for quantification of the pyrimorph-resistant and pyrimorph-sensitive allele with the real-time PCR-based method. The experiment was conducted three times. The mean FK value of the Q1077K allele in each sample was determined and compared with the value of the proportion of resistant isolates obtained by the conventional method in the competition assays.

Statistical analysis. All statistical analyses were carried out with Statistical Analysis System software version 9 (SAS Institute, Cary, NC). The observed ratios of pyrimorph-resistant and pyrimorph-sensitive isolates were compared with the theoretical expected ratios (1R:9S, 3R:7S, 5R:5S, 7R:3S, and 9R:1S) with an exact binomial (goodness-of-fit) test $(\alpha=0.05)$. This test was also used to analyze the correlation between the mean FK value of the pyrimorph-resistant allele and the average proportion of pyrimorph-resistant isolates in the same mixed sample. Linear regression was used to describe the standard curve for the quantification of the Q1077K mutation using the real-time PCR-based method and to describe the frequency at which the resistant allele was detected by the real-time PCR-based method as a function of the proportion of resistant zoospores in the tested mixtures.

\section{RESULTS}

Determination of the concentration of pyrimorph that can be used to discriminate between resistant and sensitive isolates of $\boldsymbol{P}$. capsici. The hyphal growth on CA of the sensitive isolates $\mathrm{Hd} 3$ and $\mathrm{Hd} 11$ was completely inhibited by pyrimorph at 8 and $10 \mu \mathrm{g} / \mathrm{ml}$, respectively, while the two pyrimorph-resistant isolates, R3-2 and R11-1, grew well on the medium amended with $15 \mu \mathrm{g}$ of pyrimorph/ml (Fig. 1). Therefore, $15 \mu \mathrm{g}$ of pyri$\mathrm{morph} / \mathrm{ml}$ was selected as the concentration for discriminating between pyrimorph-resistant and pyrimorph-sensitive isolates of P. capsici.

Competitive ability in vitro. Exact binomial analyses indicated no significant difference $(P>0.05)$ between the observed and expected ratio between pyrimorph-resistant and pyrimorphsensitive isolates after the first transfer (Table 1). After the fifth transfer, however, the observed frequency of pyrimorph-resistant isolates was less than the expected frequency in some cases

TABLE 1. In vitro competition between pyrimorph-sensitive and -resistant isolates of Phytophthora capsici as indicated by exact binomial tests of expected and observed ratios after one and five subcultures on agar medium ${ }^{\mathrm{a}}$

\begin{tabular}{|c|c|c|c|c|c|c|c|}
\hline \multirow{2}{*}{$\begin{array}{l}\text { Isolate } \\
\text { combination }\end{array}$} & \multirow[b]{2}{*}{ Initial ratios ${ }^{b}$} & \multirow[b]{2}{*}{ Expected (R:S) } & \multicolumn{2}{|c|}{ Ratios after 1st subculture } & \multicolumn{3}{|c|}{ Ratios after 5 th subculture } \\
\hline & & & Observed (R:S) & $P$ value & Expected (R:S) & Observed (R:S) & $P$ value \\
\hline \multirow[t]{5}{*}{ Hd3 and R3-2 } & 1R:9S & $10: 90$ & $17: 83$ & $0.1475 \mathrm{~ns}^{\mathrm{c}}$ & $10: 90$ & $16: 84$ & $0.2071 \mathrm{~ns}$ \\
\hline & 3R:7S & $30: 70$ & 29:71 & $0.8768 \mathrm{~ns}$ & $30: 70$ & $35: 65$ & $0.4503 \mathrm{~ns}$ \\
\hline & $5 \mathrm{R}: 5 \mathrm{~S}$ & $50: 50$ & $50: 50$ & $1.0000 \mathrm{~ns}$ & $50: 50$ & $52: 48$ & $0.7773 \mathrm{~ns}$ \\
\hline & $7 \mathrm{R}: 3 \mathrm{~S}$ & $70: 30$ & $63: 37$ & $0.4503 \mathrm{~ns}$ & $70: 30$ & $72: 28$ & $0.4503 \mathrm{~ns}$ \\
\hline & 9R:1S & $90: 10$ & $88: 12$ & $0.6513 \mathrm{~ns}$ & $90: 10$ & $80: 20$ & $0.0477 * \mathrm{~d}$ \\
\hline \multirow[t]{5}{*}{ Hd11 and R11-1 } & 1R:9S & $10: 90$ & $16: 84$ & $0.2071 \mathrm{~ns}$ & $10: 90$ & $11: 89$ & $0.8176 \mathrm{~ns}$ \\
\hline & 3R:7S & $30: 70$ & $38: 62$ & $0.2324 \mathrm{~ns}$ & $30: 70$ & $12: 88$ & $0.0018 *$ \\
\hline & $5 \mathrm{R}: 5 \mathrm{~S}$ & $50: 50$ & $56: 44$ & $0.3952 \mathrm{~ns}$ & $50: 50$ & $36: 64$ & $0.0455^{*}$ \\
\hline & $7 \mathrm{R}: 3 \mathrm{~S}$ & $70: 30$ & $66: 34$ & $0.5443 \mathrm{~ns}$ & $70: 30$ & $55: 45$ & $0.0285^{*}$ \\
\hline & 9R:1S & $90: 10$ & $82: 18$ & $0.1030 \mathrm{~ns}$ & $90: 10$ & $70: 30$ & $0.0040^{*}$ \\
\hline
\end{tabular}

\footnotetext{
${ }^{a}$ Ratios were determined by the conventional method (isolation on a pyrimorph-amended medium)

b Pyrimorph-resistant isolates:pyrimorph-sensitive isolates (R:S).

${ }^{\mathrm{c}} \mathrm{ns}$ indicates that observed ratios were not significantly different from expected ratios $(\alpha=0.05)$.

$\mathrm{d} *$ indicates that observed ratios were significantly different from expected ratios $(\alpha=0.05)$.
} 
(Table 1). The drop in observed frequency of pyrimorph-resistant isolates was more evident with the combination of Hd11 and R111 than with the combination of Hd3 and R3-2 (Table 1). These in vitro results indicated that the pyrimorph-resistant isolates were less fit than the pyrimorph-sensitive isolates.

Competitive ability in planta. With respect to in planta competition, observed and expected ratios of resistant and sensitive isolates of the two combinations did not significantly differ $(P>$ $0.05)$ after the first disease cycle (Table 2). After the fifth and tenth disease cycle, however, the observed frequency of pyrimorph-resistant isolates was less than the expected frequency in some cases (Table 2). As was the case with in vitro results, these in vivo results indicated that sensitive isolates were better competitors than resistant isolates.

Detection and quantification of the Q1077K mutation by a real-time PCR-based method. A standard curve was produced for the detection of the pyrimorph-resistance allele of (Q1077K) of $P$. capsici using a serial dilution of template DNA from the resistant isolates R3-2 and R11-1 and primers (Supplemental Figure 1). A similar curve was produced for the detection of the pyrimorph-sensitive allele (Q1077) of $P$. capsici using serial dilutions of template DNA from the sensitive isolates $\mathrm{Hd} 3$ and Hd11 and primers. The standard curves demonstrated that the real-time PCR assay described here could be used to quantify the pyrimorph-resistant and pyrimorph-sensitive alleles.

A linear relationship $\left(P<0.0001, R^{2}=0.9369\right)$ was obtained between the proportions of pyrimorph-resistant isolate R3-2 in the zoospore suspension mixture and the FK values detected with the real-time PCR assay (Fig. 2). The results demonstrated that the real-time PCR assay could be used to quantify the pyrimorph- resistant allele Q1077K in real samples in which the frequency of the pyrimorph-resistant allele is unknown.

Comparison of the real-time PCR assay with the conventional method. Selected zoospore mixtures from the in vitro and in planta competition tests, which had been subjected to the conventional assay, were subjected to the real-time PCR assay. According to the exact binomial test, the average FK value obtained by real-time PCR did not significantly differ from the observed proportion of pyrimorph-resistant isolate obtained by the conventional method $(P>0.05)$ (Table 3$)$.

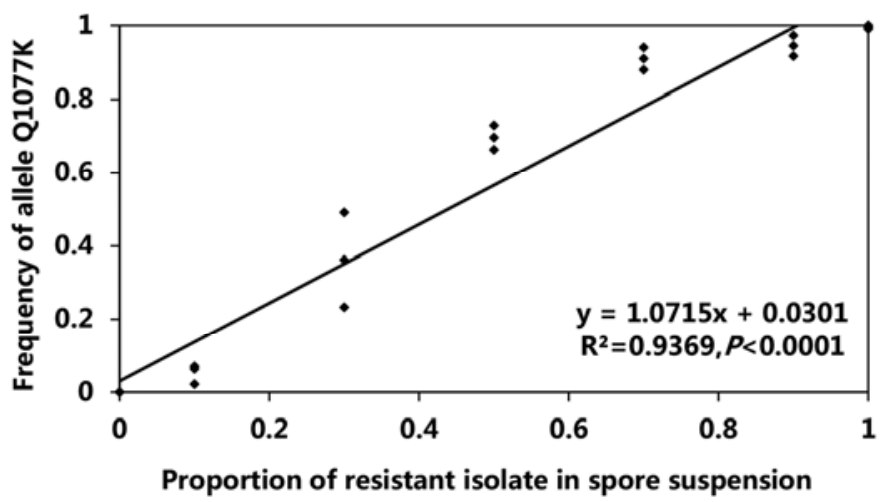

Fig. 2. Relationship between the frequency of the pyrimorph-resistant allele Q1077K, determined with the real-time polymerase chain reaction assay, and the corresponding known proportions of spores of the pyrimorph-resistant isolate in suspensions containing mixtures of spores from pyrimorph-resistant and -sensitive isolates. Each mixture was represented by three replicates.

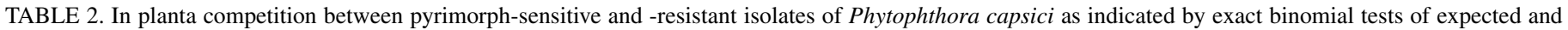
observed ratios after 1, 5, and 10 disease cycles (inoculations and isolations) from pepper plants ${ }^{\mathrm{a}}$

\begin{tabular}{|c|c|c|c|c|c|c|c|c|c|c|}
\hline \multirow[b]{2}{*}{$\begin{array}{l}\text { Isolate } \\
\text { combination }\end{array}$} & \multirow[b]{2}{*}{$\begin{array}{l}\text { Inoculation } \\
\text { ratios }^{b}\end{array}$} & \multicolumn{3}{|c|}{ Ratios after 1 disease cycle } & \multicolumn{3}{|c|}{ Ratios after 5 disease cycles } & \multicolumn{3}{|c|}{ Ratios after 10 disease cycles } \\
\hline & & $\begin{array}{l}\text { Expected } \\
\text { (R:S) }\end{array}$ & $\begin{array}{l}\text { Observed } \\
\text { (R:S) }\end{array}$ & $P$ value & $\begin{array}{c}\text { Expected } \\
\text { (R:S) }\end{array}$ & $\begin{array}{l}\text { Observed } \\
\text { (R:S) }\end{array}$ & $P$ value & $\begin{array}{l}\text { Expected } \\
(\mathrm{R}: \mathrm{S})\end{array}$ & $\begin{array}{l}\text { Observed } \\
\text { (R:S) }\end{array}$ & $P$ value \\
\hline \multirow[t]{5}{*}{$\mathrm{Hd} 3$ and R3-2 } & 1R:9S & $10: 90$ & $4: 96$ & $0.0963 \mathrm{~ns}^{\mathrm{c}}$ & $10: 90$ & $0: 100$ & $0.0012^{* \mathrm{~d}}$ & $10: 90$ & $0: 100$ & $0.0012 *$ \\
\hline & 3R:7S & $30: 70$ & $32: 68$ & $0.7598 \mathrm{~ns}$ & $30: 70$ & 39:61 & $0.1807 \mathrm{~ns}$ & $30: 70$ & $33: 67$ & $0.6479 \mathrm{~ns}$ \\
\hline & $5 \mathrm{R}: 5 \mathrm{~S}$ & $50: 50$ & $53: 47$ & $0.6712 \mathrm{~ns}$ & $50: 50$ & $52: 48$ & $0.7773 \mathrm{~ns}$ & $50: 50$ & 40:60 & $0.1552 \mathrm{~ns}$ \\
\hline & $7 \mathrm{R}: 3 \mathrm{~S}$ & $70: 30$ & $78: 22$ & $0.1972 \mathrm{~ns}$ & $70: 30$ & $74: 26$ & $0.5287 \mathrm{~ns}$ & $70: 30$ & $64: 36$ & $0.3669 \mathrm{~ns}$ \\
\hline & 9R:1S & 90:10 & $88: 12$ & $0.6513 \mathrm{~ns}$ & 90:10 & $71: 29$ & $0.0007 *$ & 90:10 & $68: 32$ & $<0.0001 *$ \\
\hline \multirow[t]{5}{*}{ Hd11 and R11-1 } & 1R:9S & $10: 90$ & $5: 95$ & $0.0963 \mathrm{~ns}$ & $10: 90$ & $0: 100$ & $0.0012 *$ & $10: 90$ & $0: 100$ & $0.0012 *$ \\
\hline & 3R:7S & $30: 70$ & $35: 65$ & $0.4503 \mathrm{~ns}$ & $30: 70$ & $24: 76$ & $0.3393 \mathrm{~ns}$ & $30: 70$ & $27: 73$ & $0.6384 \mathrm{~ns}$ \\
\hline & $5 \mathrm{R}: 5 \mathrm{~S}$ & $50: 50$ & $55: 45$ & $0.4790 \mathrm{~ns}$ & $50: 50$ & $53: 47$ & $0.6712 \mathrm{~ns}$ & $50: 50$ & $48: 52$ & $0.7773 \mathrm{~ns}$ \\
\hline & $7 \mathrm{R}: 3 \mathrm{~S}$ & $70: 30$ & $78: 22$ & $0.1972 \mathrm{~ns}$ & $70: 30$ & $75: 25$ & $0.4285 \mathrm{~ns}$ & $70: 30$ & $63: 37$ & $0.2943 \mathrm{~ns}$ \\
\hline & 9R:1S & $90: 10$ & $82: 18$ & $0.1475 \mathrm{~ns}$ & $90: 10$ & $83: 17$ & $0.1475 \mathrm{~ns}$ & $90: 10$ & $79: 21$ & $0.0316^{*}$ \\
\hline
\end{tabular}

a Ratios were determined by the conventional method (isolation on a pyrimorph-amended medium).

b Pyrimorph-resistant isolates:pyrimorph-sensitive isolates (R:S).

${ }^{\mathrm{c}}$ ns indicates that observed ratios were not significantly different from expected ratios $(\alpha=0.05)$.

$\mathrm{d} *$ indicates that observed ratios were significantly different from expected ratios $(\alpha=0.05)$.

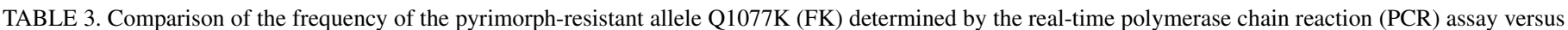

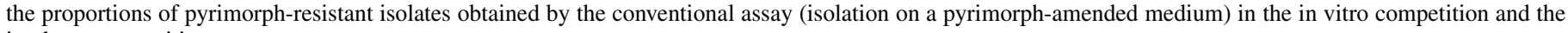
in planta competition tests

\begin{tabular}{|c|c|c|c|c|c|}
\hline \multirow[b]{2}{*}{ Combination } & \multirow[b]{2}{*}{ Initial inoculation ratio ${ }^{a}$} & \multicolumn{2}{|c|}{ In vitro (after the 5 th subculture) } & \multicolumn{2}{|c|}{ In planta (after the 10th disease cycle) } \\
\hline & & FK & $P$ value ${ }^{\mathrm{b}}$ & FK & $P$ value ${ }^{b}$ \\
\hline \multirow[t]{5}{*}{$\mathrm{Hd} 3$ and R3-2 } & 1R:9S & 0.084 & 0.0817 & 0.007 & 0.3161 \\
\hline & $3 R: 7 S$ & 0.315 & 0.6531 & 0.234 & 0.1153 \\
\hline & $5 \mathrm{R}: 5 \mathrm{~S}$ & 0.495 & 0.7773 & 0.356 & 0.5601 \\
\hline & $7 \mathrm{R}: 3 \mathrm{~S}$ & 0.671 & 0.4425 & 0.621 & 0.1326 \\
\hline & 9R:1S & 0.782 & 0.7284 & 0.716 & 0.5371 \\
\hline \multirow[t]{5}{*}{ Hd11 and R11-1 } & 1R:9S & 0.051 & 0.1179 & 0.000 & 1.0000 \\
\hline & $3 R: 7 S$ & 0.159 & 0.4150 & 0.318 & 0.4382 \\
\hline & $5 \mathrm{R}: 5 \mathrm{~S}$ & 0.373 & 0.8832 & 0.583 & 0.1566 \\
\hline & $7 \mathrm{R}: 3 \mathrm{~S}$ & 0.648 & 0.1489 & 0.726 & 0.1296 \\
\hline & 9R:1S & 0.733 & 0.6384 & 0.774 & 0.7328 \\
\hline
\end{tabular}

a Pyrimorph-resistant isolates:pyrimorph-sensitive isolates (R:S).

b $P$ values compare frequencies/proportions detected by the PCR assay versus the conventional assay. None of the $P$ values was significant $(\alpha=0.05)$. 


\section{DISCUSSION}

In this study, we investigated the competitive ability of pyrimorph-resistant versus pyrimorph-sensitive isolates of $P$. capsici in vitro and in planta so as to better understand the fitness of the pyrimorph-resistant isolates. To our knowledge, this is the first report concerning the "realized fitness" $(1,3,9)$ of the resistance to pyrimorph in $P$. capsici. Pyrimorph, which can be used alone or in combination with other fungicides, has become an important tool for control of $P$. capsici $(12,14,36)$. The results presented here on the fitness of pyrimorph-resistant isolates provide the basic knowledge required to develop effective strategies for the management of $P$. capsici.

A discriminatory concentration has been used to differentiate between fungicide-resistant and pyrimorph-sensitive isolates in several studies $(4,9,40)$. In this study, a medium amended with $15 \mu \mathrm{g}$ of pyrimorph/ml prevented the growth of sensitive isolates but not the growth of resistant isolates of $P$. capsici. Having identified a discriminatory concentration of pyrimorph, we compared the competitive ability of resistant and sensitive isolates with a conventional assay based on the response of the recovered zoospore isolates to this discriminatory concentration of pyrimorph in an agar medium. The results were consistent with our previous study, in which all 226 pyrimorph-sensitive field isolates used for baseline sensitivity were completely inhibited by $15 \mu \mathrm{g} / \mathrm{ml}$ of pyrimorph (30); in that same study, 12 pyrimorphresistant mutants obtained by repeated exposure to pyrimorph grew well at this concentration.

Rather than test the competitive ability of one combination of pyrimorph-resistant and pyrimorph-sensitive isolates at one inoculum ratio, we use two combinations of isolates and five ratios of resistant: sensitive zoospores as inoculum. This approach was chosen because it more closely reflects nature, where diverse isolates with different phenotypes in respect to fungicide sensitivity compete for dominance. As demonstrated in previous studies, experimental variations in competitive ability may result not only from fitness costs associated with fungicide resistance genes but also from differences in the isolates tested $(7,21,41)$. Differences were evident in the competition tests of the current study in that the two combinations of pyrimorph-resistant and pyrimorphsensitive isolates differed in some cases in the in vitro competition test. For the combination of $\mathrm{Hd} 3$ and R3-2, the recovery of resistant and sensitive isolates was as expected from the proportions introduced at ratios of $3 \mathrm{R}: 7 \mathrm{~S}, 5 \mathrm{R}: 5 \mathrm{~S}$, and $7 \mathrm{R}: 3 \mathrm{~S}$. For the combination of Hd11 and R11-1, however, the proportion of the resistant isolate recovered significantly decreased at these ratios. For each pair of combinations in the in planta test, the resistant isolate became nondetectable at the initial ratio of 1R:9S, which was not the case with the other ratios.

We determined the competitive ability of pyrimorph-resistant versus pyrimorph-sensitive isolates of $P$. capsici in vitro and in planta with both a conventional method and a newly developed real-time PCR assay. The results obtained by the two methods were similar, confirming the utility of the real-time PCR assay. The real-time PCR assay that was developed here requires much less time and labor than the conventional method and will be valuable for monitoring the development and prevalence of pyrimorph resistance in $P$. capsici populations. Because $P$. capsici can spread rapidly and cause epidemics, the ability to rapidly detect fungicide resistance and adjust disease management accordingly is important $(2,13,26,27)$.

When the initial percentage of resistant isolates was $10 \%$ in our in planta competition tests in the absence of pyrimorph, no resistant isolates were recovered from diseased pepper stems after five disease cycles. In most cases, however, the pyrimorph-resistant isolates were able to compete with the pyrimorph-sensitive isolates in vitro and in planta, although ratios of resistant isolates recovered were often lower than ratios initially applied. In some cases, the ratio recovered did not significantly differ from the ratio applied. These results suggest that pyrimorph-resistant isolates may be able to compete with the pyrimorph-sensitive isolates even in the absence of the fungicide. Because of the importance of pyrimorph for the control of $P$. capsici, future research is needed to monitor the dynamics of pyrimorph-resistant populations in fields where pyrimorph is still being used or has been discontinued. Such information will be important for the development and implementation of fungicide resistancemanagement practices. The required monitoring will be facilitated by the real-time PCR assay described in this report.

\section{ACKNOWLEDGMENTS}

This work was funded by the National Science Foundation of China (31071705), special Fund for Agro-scientific Research in the Public Interest (201303023, 210203022) and Chinese Universities Scientific Fund (2013YJ001). We thank B. Jaffee for reviewing and providing professional opinions on this manuscript.

\section{LITERATURE CITED}

1. Antonovics, J., and Alexander, H. M. 1989. The concept of fitness in plant-fungal pathogen systems. Pages 185-214 in: Plant Disease Epidemiology, Vol. 2. K. J. Leonard and W. E. Fry, eds. McGraw and Hill, New York.

2. Aoki, Y., Furuya, S., and Suzuki, S. 2011. Method for rapid detection of the $P v C e s A 3$ gene allele conferring resistance to mandipropamid, a carboxylic acid amide fungicide, in Plasmopara viticola populations. Pest Manag. Sci. 67:1557-1561.

3. Bardas, G. A., Myresiotis, C. K., and Karaoglanidis, G. S. 2008. Stability and fitness of anilinopyrimidine-resistant strains of Botrytis cinerea. Phytopathology 98:443-450.

4. Baroffio, C. A., Siegfried, W., and Hilber, U. W. 2003. Long-term monitoring for resistance of Botryotinia fuckeliana to anilinopyrimidine, phenylpyrrole, and hydroxyanilide fungicides in Switzerland. Plant Dis. 87:662-666.

5. BASF SE. 2010. Method for combating harmful fungi. Patent No. US2012083497A1.

6. BASF SE. 2010. Method for reducing nitrous oxide emission from soils. Patent No. US2012252668A1.

7. Chapara, V., Taylor, R. J., Pasche, J. S., and Gudmestad, N. C. 2010. Prevalence of mefenoxam resistance among Phytophthora erythroseptica Pethybridge isolates in Minnesota and North Dakota. Am. J. Potato Res. 87:521-530.

8. Chapara, V., Taylor, R. J., Pasche, J. S., and Gudmestad, N. C. 2011. Competitive parasitic fitness of mefenoxam-sensitive and -resistant isolates of Phytophthora erythroseptica under fungicide selection pressure. Plant Dis. 95:691-696.

9. Chapeland, F., Fritz, R., Lanen, C., Gredt, M., and Leroux, P. 1999. Inheritance and mechanisms of resistance to anilinopyrimidine fungicides in Bortytis cinerea (Botryotinia Fuckeliana). Pestic. Biochem. Physiol. 64:85-100.

10. Crossan, D. F., Haasis, F. A., and Ellis, D. E. 1954. Phytophthora blight of summer squash. Plant Dis. Rep. 38:557-559.

11. Davidson, C., Carroll, R., Evans, T., Mulrooney, R., and Kim, S. 2002. First report of Phytophthora capsici infecting lima bean (Phaseolus lunatus) in the Mid-Atlantic region. Plant Dis. 86:1049-1049.

12. Dietz, J., Gewehr, M., and Haden, E. 2012. Fungicidal composition, useful e.g. for controlling phytopathogenic or harmful fungi, comprises active compound comprising e.g. fluopyram, and another active compound, such as strobilurins, azoles, heterocyclic compounds, and biologicals. Patent No. WO2012016989-A2; WO2012016989-A3.

13. Dufour, M. C., Fontaine, S., Montarry, J., and Corio-Costet, M. F. 2011. Assessment of fungicide resistance and pathogen diversity in Erysiphe necator using quantitative real-time PCR assays. Pest Manag. Sci. 67:6069.

14. Gao, C., and Zhang, Q. 2010. Fungicidal composition useful for preventing and controlling diseases caused by oomycetes, downy mildew and Phytophthora, comprises pyrimorph and cyazofamid as active ingredients. Patent No. CN101971827-A.

15. Gevens, A. J., Donahoo, R. S., Lamour, K. H., and Hausbeck, M. K. 2007 Characterization of Phytophthora capsici from Michigan surface irrigation water. Phytopathology 97:421-428.

16. Hausbeck, M. K., and Lamour, K. H. 2004. Phytophthora capsici on vegetable crops: Research progress and management challenges. Plant Dis. 88:1292-1303. 
17. Hwang, B. K., and Kim, C. H. 1995. Phytophthora blight of pepper and its control in Korea. Plant Dis. 79:221-227.

18. Kadish, D., and Cohen, Y. 1988. Fitness of Phytophthora infestans isolates from metalaxyl-sensitive and -resistant populations. Phytopathology 78:912-915.

19. Karaoglanidis, G., Luo, Y., and Michailides, T. 2011. Competitive ability and fitness of Alternaria alternata isolates resistant to QoI fungicides. Plant Dis. 95:178-182.

20. Keinath, A. P. 2007. Sensitivity of populations of Phytophthora capsici from South Carolina to mefenoxam, dimethomorph, zoxamide, and cymoxanil. Plant Dis. 91:743-748.

21. Kim, Y., and Xiao, C. 2011. Stability and fitness of pyraclostrobin-and boscalid-resistant phenotypes in field isolates of Botrytis cinerea from apple. Phytopathology 101:1385-1391.

22. Lamour, K., and Hausbeck, M. 2000. Mefenoxam insensitivity and the sexual stage of Phytophthora capsici in Michigan cucurbit fields. Phytopathology 90:396-400.

23. Lamour, K. H., Stam, R., Jupe, J., and Huitema, E. 2012. The oomycete broad-host-range pathogen Phytophthora capsici. Mol. Plant Pathol. 13:329-337.

24. Leonian, L. H. 1922. Stem and fruit blight of peppers caused by Phytophthora capsici $\mathrm{sp}$. nov. Phytopathology 12:401-408.

25. Luo, N., Pereira, S., Sahin, O., Lin, J., and Huang, S. 2005. Enhanced in vivo fitness of fluoroquinolone-resistant Campylobacter jejuni in the absence of antibiotic selection pressure. Proc. Natl. Acad. Sci. USA 102:541-546

26. Luo, Y., Ma, Z., Reyes, H. C., Morgan, D. P., and Michailides, T. J. 2007. Using real-time PCR to survey frequency of azoxystrobin-resistant allele G143A in Alternaria populations from almond and pistachio orchards in California. Pest. Biochem. Physiol. 88:328-336.

27. Ma, Z. H., and Michailides, T. J. 2004. A real-time PCR assay for the detection of azoxystrobin-resistant Alternaria populations from pistachio orchards in California. Crop Prot. 23:1259-1263.

28. Mitani, S., Araki, S., Yamaguchi, T., Takii, Y., Ohshima, T., and Matsuo, N. 2001. Antifungal activity of the novel fungicide cyazofamid against Phytophthora infestans and other plant pathogenic fungi in vitro. Pestic. Biochem. Physiol. 70:92-99.

29. Ortega, R. G., Español, C. P., and Zueco, J. C. 1991. Genetics of resistance to Phytophthora capsici in the pepper line 'SCM-334'. Plant breeding 107:50-55.

30. Pang, Z., Shao, J., Chen, L., Lu, X., and Hu, J. 2013. Resistance to the novel fungicide pyrimorph in Phytophthora capsici: Risk assessment and detection of point mutations in CesA3 that confer resistance. PloS One 8:e56513.

31. Parnell, S., Gilligan, C. A., and Van den Bosch, F. 2005. Small-scale fungicide spray heterogeneity and the coexistence of resistant and sensitive pathogen strains. Phytopathology 95:632-639.

32. Parra, G., and Ristaino, J. B. 2001. Resistance to mefenoxam and metalaxyl among field isolates of Phytophthora capsici causing Phytophthora blight of bell pepper. Plant Dis. 85:1069-1075.

33. Peever, T. L., and Milgroom, M. G. 1995. Fungicide resistance: Lessons for herbicide resistance management. Weed Technol. 9:840-849.

34. Pringle, A., and Taylor, J. W. 2002. The fitness of filamentous fungi. Trends Microbiol. 10:474-481.

35. Qi, R., Wang, T., Zhao, W., Li, P., Ding, J., and Gao, Z. 2012. Activity of ten fungicides against Phytophthora capsici isolates resistant to metalaxyl. J. Phytopathol. 160:717-722.

36. Qin, Z., Mu, C., Li, N., Fu, B., Zhang, S., and Xiao, Y. 2007. Agricultural bacteriocide-pyrimorph involves mixing compound with surfactant other assistants and grinding to obtain suspension, frosty mildew of cucumber, blight of hot pepper, proportional mixing compound A with surfactant and grinding. Patent No. CN1939128-A; WO2007137462-A1.

37. Ristaino, J. 1990. Intraspecific variation among isolates of Phytophthore capsici from pepper and cucurbit fields in North Carolina. Phytopathology 80:1253-1259.

38. Ristaino, J. B., Madritch, M., Trout, C. L., and Parra, G. 1998. PCR amplification of ribosomal DNA for species identification in the plant pathogen genus Phytophthora. Appl. Environ. Microbiol. 64:948-954.

39. Schmitthenner, A., and Bhat, R. G. 1994. Useful methods for studying Phytophthora in the laboratory. Special Circ. 0736-8003.

40. Sun, H., Wang, H., Stammler, G., Ma, J., and Zhou, M. 2010. Baseline Sensitivity of populations of Phytophthora capsici from China to three carboxylic acid amide (CAA) fungicides and sequence analysis of cholinephosphotranferases from a CAA-sensitive isolate and CAAresistant laboratory mutants. J. Phytopathol. 158:244-252.

41. Timmer, L., Graham, J., and Zitko, S. 1998. Metalaxyl-resistant isolates of Phytophthora nicotianae: Occurrence, sensitivity, and competitive parasitic ability on citrus. Plant Dis. 82:254-261.

42. Luo, Y., Ma, Z., Reyes, H. C., Morgan, D. P., and Michailides, T. J. 2007. Using real-time PCR to survey frequency of azoxystrobin-resistant allele G143A in Alternaria populations from almond and pistachio orchards in California. Pest. Biochem. Physiol. 88:328-336.

43. Yan, X., Qin, W., Sun, L., Qi, S., and Yang, D., Qin, Z., and Yuan, H. 2010. Study of inhibitory effects and action mechanism of the novel fungicide pyrimorph against Phytophthora capsici. J. Agric. Food Chem. $58: 2720-2725$ 